\title{
Lung disease associated with filamin $A$ gene mutation: a case report
}

\author{
Safa Eltahir, Khalid S. Ahmad, Mohammed M. Al-Balawi , Hussien Bukhamsien, Khalid Al-Mobaireek, \\ Wadha Alotaibi and Abdullah Al-Shamrani
}

\begin{abstract}
Background: Mutations in the gene encoding filamin A (FLNA) lead to diseases with high phenotypic diversity including periventricular nodular heterotopia, skeletal dysplasia, otopalatodigital spectrum disorders, cardiovascular abnormalities, and coagulopathy. FLNA mutations were recently found to be associated with lung disease. In this study, we report a novel FLNA gene associated with significant lung disease and unique angiogenesis.
\end{abstract}

Case presentation: Here, we describe a 1-year-old Saudi female child with respiratory distress at birth. The child then had recurrent lower respiratory tract infections, bilateral lung emphysema with basal atelectasis, bronchospasm, pulmonary artery hypertension, and oxygen and mechanical ventilation dependency. Molecular testing showed a new pathogenic variant of one copy of c.3153dupC in exon 21 in the FLNA gene.

Conclusions: Our data support previous reports in the literature that associate FLNA gene mutation and lung disease.

Keywords: FLNA, Lung disease, Angiogenesis, Pediatrics

\section{Background}

Filamin $A$ is a $280-\mathrm{kD}$ protein that crosslinks actin filaments into orthogonal networks in cortical cytoplasm and participates in the anchoring of membrane proteins for the actin cytoskeleton. Remodeling of the cytoskeleton is central to the modulation of cell shape and migration. Filamin A, encoded by the FLNA gene, is a widely expressed protein that regulates reorganization of the actin cytoskeleton by interacting with integrins, transmembrane receptor complexes, and second messengers, thus mutations in the gene encoding filamin A (FLNA) lead to diseases with high phenotypic diversity including the following: periventricular nodular heterotopia (PNH), skeletal dysplasia, otopalatodigital spectrum disorders such as Melnick-Needles syndrome and frontometaphyseal dysplasia [1-5], cardiovascular abnormalities that include patent ductus arteriosus (PDA), valvular disease, aortic root dilatation and aneurysms, Ehlers-Danlos syndrome-like phenotype [6-8], and coagulopathy with thrombocytopenia [9]. Recently, Masurel-Paulet et al. [1],

\footnotetext{
* Correspondence: malbalawi@hotmail.com

King Fahad Medical City, P.O. Box 59046, Riyadh 11525, Kingdom of Saudi Arabia
}

(C) 2016 Eltahir et al. Open Access This article is distributed under the terms of the Creative Commons Attribution 4.0 International License (http://creativecommons.org/licenses/by/4.0/), which permits unrestricted use, distribution, and reproduction in any medium, provided you give appropriate credit to the original author(s) and the source, provide a link to the Creative Commons license, and indicate if changes were made. The Creative Commons Public Domain Dedication waiver (http://creativecommons.org/publicdomain/zero/1.0/) applies to the data made available in this article, unless otherwise stated.

\section{Case presentation}

Our patient is a 1-year-old Saudi female child who was referred from another hospital after PDA ligation, left inguinal hernia repair, accidental fracture of her right ulna and radius, and prolonged mechanical ventilation for severe respiratory syncytial virus infection complicated by acute respiratory distress syndrome. The patient was sent to our hospital for further evaluation due to ongoing respiratory distress and hypoxemia. Our patient was the third child of nonconsanguineous Saudi parents and was born via cesarean section at 36 weeks gestation due to fetal distress. The child was admitted to the neonatal intensive care unit for 5 days because of respiratory distress and was ventilated for 36 hours. The mother has epilepsy and the father has been diagnosed with Behcet's disease. Since the age of 2 months, the child had multiple lengthy admissions in different hospitals (for 1 to 3 
months at a time) for recurrent cyanotic events, respiratory distress, frequent choking with feeding, and significant vomiting. The child had accumulated the following diagnoses: severe gastroesophageal reflux disease (GERD), failure to thrive requiring prolonged nasogastric tube feeding, patent ductus arteriosus, pulmonary hypertension, anoxic convulsions, chronic lung disease with prolonged oxygen dependency, reversible bronchospasm, left external iliac vein thrombosis, and developmental delay. She had two prior prolonged stays at our institution.

The first admission was due to rhinovirus infection and clinically diagnosed recurrent aspiration secondary to aberrant right subclavian artery (dysphagia lusoria) with prolonged oxygen therapy. The second admission was for respiratory failure that required prolonged intubation including high-frequency oscillatory ventilation complicated by recurrent lung atelectasis and right lung pneumothorax. She failed multiple trials of extubation and unfortunately died of cardiac arrest due to sepsis while receiving maximal supportive therapy. An initial physical examination during the first admission revealed a baby girl in poor health with the following clinical values: moderate respiratory distress and a respiratory rate of $70 / \mathrm{min}$, heart rate of $144 / \mathrm{min}$, blood pressure of $101 / 47$ with saturation of $95 \%$ on $1.5 \mathrm{~L} / \mathrm{min}$, body weight of $5.9 \mathrm{~kg}$ (below the third percentile), and height of $69 \mathrm{~cm}$ (at the tenth percentile).The child had diminished breath sounds bilaterally with a prolonged expiratory phase, wheezing, and scattered crackles posteriorly, mild hypotonia, and significant hyperlaxity. Investigations showed normal sweat chloride level, and immune function testing was normal. A chest X-ray (Fig. 1) showed multiple subsegmental atelectasis and areas of

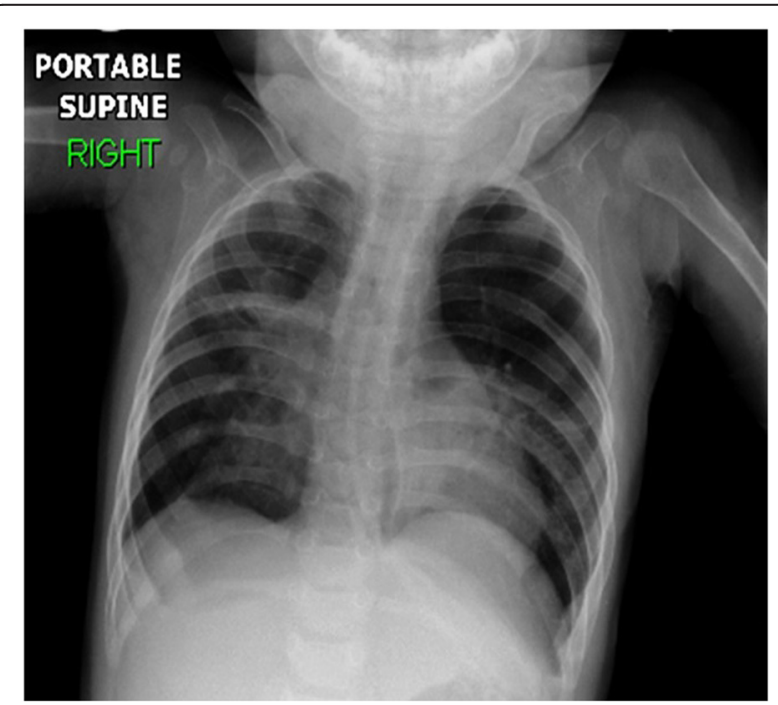

Fig. 1 Chest $X$-ray anteroposterior view shows multiple subsegmental atelectasis, areas of air trapping and osteopenia air trapping. Computed tomography and angiography of her chest (Fig. 2) revealed bilateral lower lobe airspace disease, hyperinflation of the right middle lobe and left upper lobe including the lingual, and an enlarged main pulmonary artery. The sagittal view (Fig. 3) showed a right aberrant subclavian artery causing posterior compression to the esophagus at the level of the T4 vertebra and minimal compression in the posterior trachea. An echocardiogram showed no residual PDA or significant evidence of pulmonary hypertension. Barium administration (Fig. 4) showed external compression along the posterior wall of the proximal third of the esophagus, which was causing significant narrowing of the esophageal lumen. The $\mathrm{pH}$ probe showed no significant GERD. Upper gastrointestinal endoscopy showed there was a narrowed and compressed area located $18 \mathrm{~cm}$ into the esophagus at T4, and was identified with marked pulsation. The flexible bronchoscopy showed complete ring and narrowing of the lower third of the trachea. A lung biopsy (Fig. 5) showed alveolated lung parenchyma with alveolar simplification, in which alveoli do not show ageappropriate normal architecture, compared with the normal alveolar architecture (Fig. 6). There was no magnetic resonance imaging (MRI) of the brain because our patient's condition did not allow it.

\section{Gene analysis}

Molecular testing for FLNA-related disorders in our patient showed a new pathogenic variant of one copy of c.3153dupC in exon 21 in the FLNA gene. This variant has not been reported in individuals with FLNA-related disorders but is expected to cause disease.

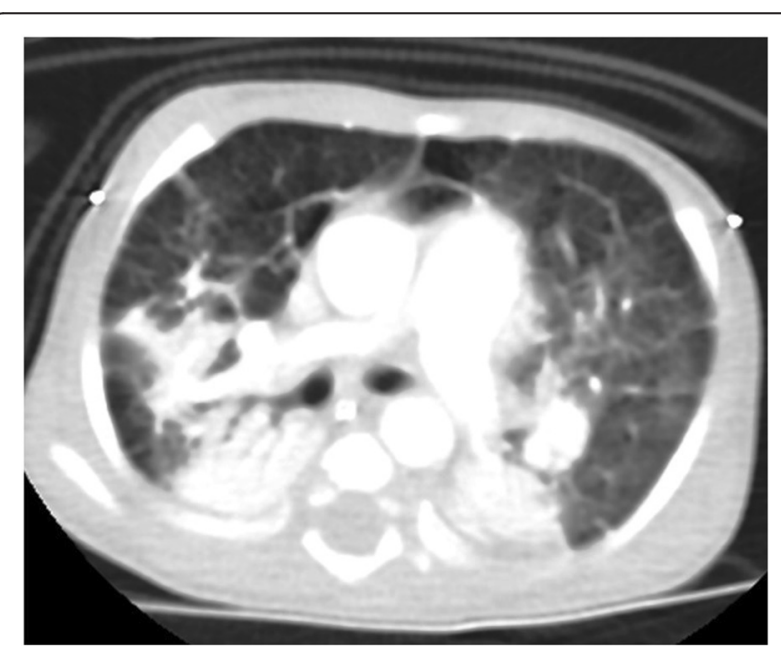

Fig. 2 Computed tomography angiography axial view below bifurcation of carina shows basal lung atelectasis, lung hyperinflation, and enlarged main pulmonary artery 


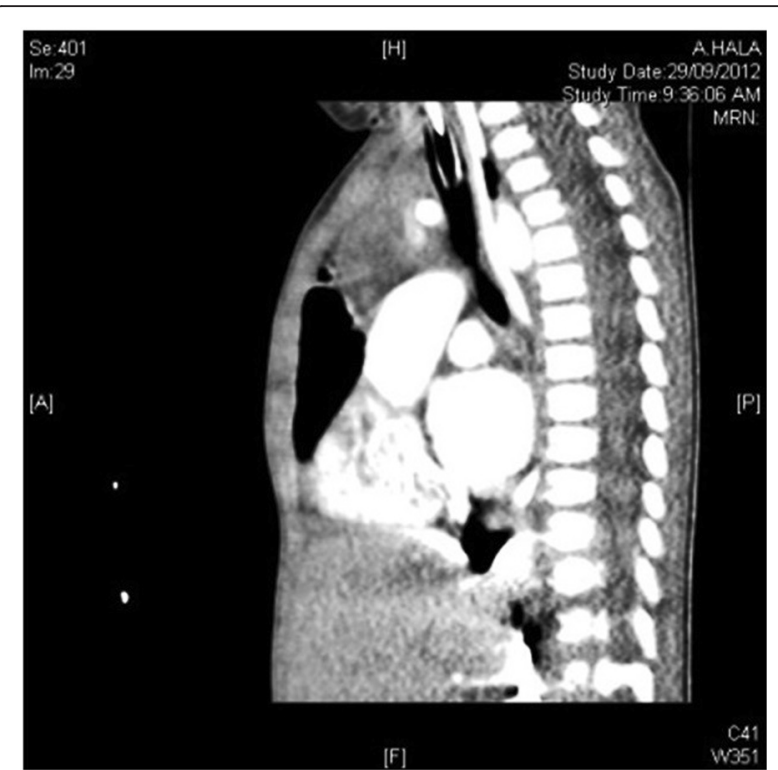

Fig. 3 Computed tomography angiography sagittal view shows right aberrant subclavian artery posterior compression to the esophagus at level of T4 vertebra and minimal compression in the posterior trachea

\section{Discussion}

In this case report, we describe another confirmatory mutation in the gene encoding filamin $\mathrm{A}$ (FLNA) in a female child with lung disease. Our patient was a female child who was confirmed to have a pathogenic variant of the FLNA gene c.3153dupC. This mutation has not been reported in individuals with FLNA-related disorders but is expected to cause disease. Similar to other reported

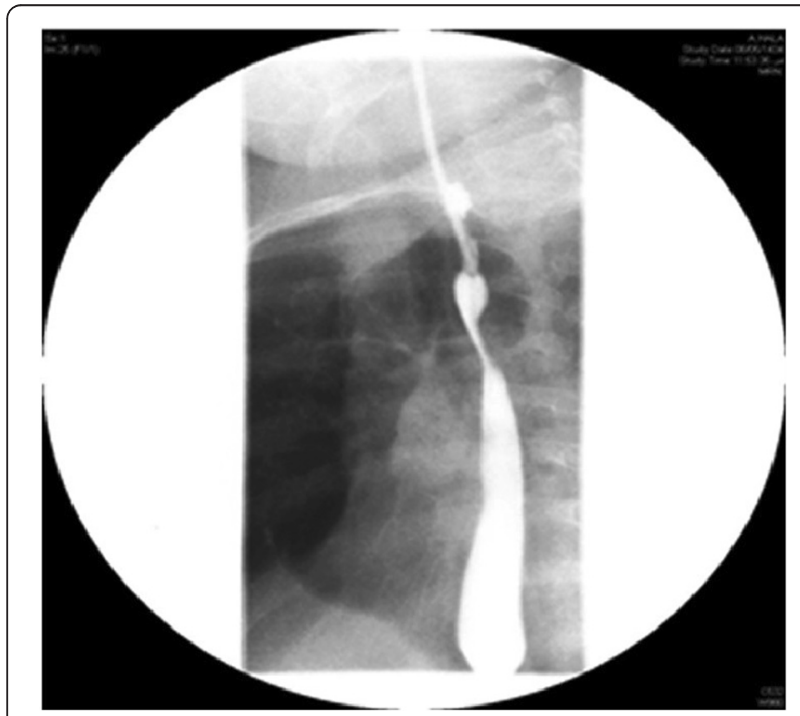

Fig. 4 Barium meal shows external compression noted along posterior wall of proximal third of the thoracic esophagus causing significant narrowing of esophageal lumen

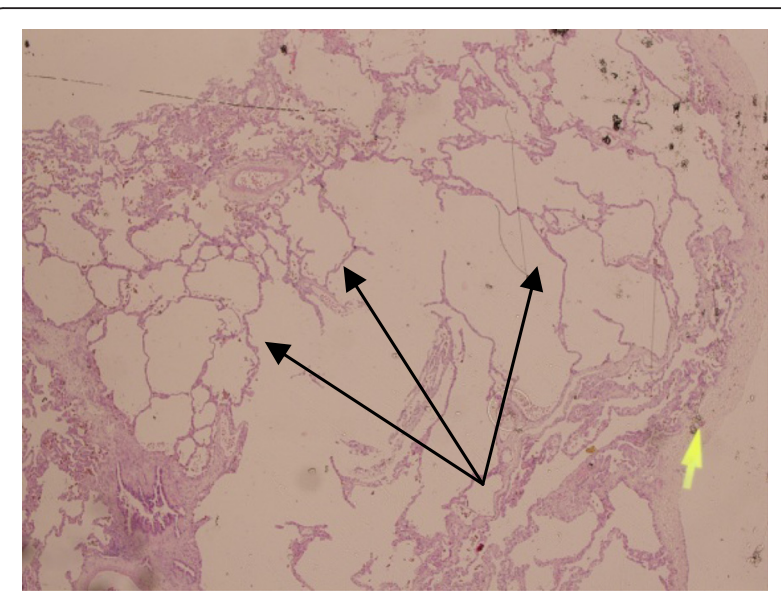

Fig. 5 Alveolated lung parenchyma (black arrows) with alveolar simplification. Small yellow arrow: from the microscope that is probably not relevant

cases, our child also manifested clinical symptoms at an early age $[10,11]$. She had respiratory distress at birth and then had recurrent lower respiratory tract infections/ bronchiolitis, bilateral lung emphysema with basal atelectasis, bronchospasm, pulmonary artery hypertension, and long oxygen and mechanical ventilatory dependency after 2 months of age. A lung biopsy showed alveolated lung parenchyma with alveolar simplification similar to the finding by Lord et al. [11]. This child also manifested associated clinical features reported with other filamin gene mutations including patent ductus arteriosis (PDA), hypotonia, joint laxity, and developmental delay [10]. These clinical and histological features are similar to cases reported with the pulmonary phenotype of FLNA (Table 1). However, an unusual clinical manifestation in our case is severe reflux that caused recurrent aspiration symptoms and dysphagia lusoria (secondary to aberrant right subclavian artery that caused significant esophageal compression). This abnormal angiogenesis has been reported only in FLNA-null mice, which have

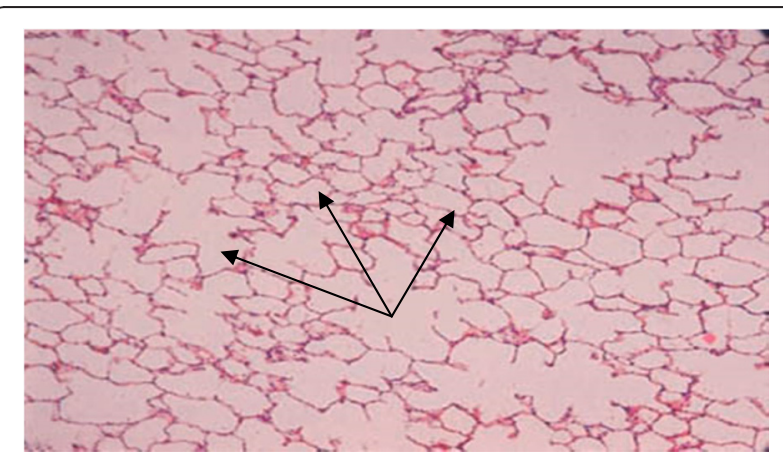

Fig. 6 Normal alveolar septation 
Table 1 Features of reported cases of filamin A mutation

\begin{tabular}{|c|c|c|c|c|}
\hline & Masurel-Paulet et al. [1] & de Wit et al. [10] & Lord et al. [11] & This case \\
\hline Genetic mutation & $\begin{array}{l}\text { Mosaic nonsense filamin A mutation } \\
\text { (c.994delG.P.K331X) }\end{array}$ & $\begin{array}{l}\text { Missense filamin A mutation } \\
\text { (c.220G }>\text { P.G74R ) }\end{array}$ & $\begin{array}{l}\text { Truncating filamin A mutation } \\
\text { (c.5683G>T,p.G1895*) }\end{array}$ & $\begin{array}{l}\text { Pathogenic variant (c.3153dupC) in } \\
\text { exon } 21 \text { filamin A gene }\end{array}$ \\
\hline Sex & Male & Female & Female & Female \\
\hline Birth & $\begin{array}{l}\text { Term with uncomplicated perinatal } \\
\text { course }\end{array}$ & $\begin{array}{l}\text { Term with uncomplicated perinatal } \\
\text { course }\end{array}$ & $\begin{array}{l}\text { Premature at } 30 \text { weeks mild } \\
\text { respiratory distress resolved after } \\
48 \text { hours }\end{array}$ & $\begin{array}{l}\text { Premature at } 36 \text { weeks with respiratory } \\
\text { distress, needed ventilation for first } \\
36 \text { hours }\end{array}$ \\
\hline Age at presentation & 1.5 months & 3 months & 24 days & 2 months \\
\hline $\begin{array}{l}\text { Pulmonary manifestation } \\
\text { and pathology }\end{array}$ & $\begin{array}{l}\text { Tachypnea, recurrent respiratory } \\
\text { infections, asthma, prolonged oxygen } \\
\text { dependence, lung atelectasis and lung } \\
\text { cysts, tracheobronchomalacia, pulmonary } \\
\text { arterial hypertension }\end{array}$ & $\begin{array}{l}\text { Dyspnea, recurrent respiratory infections, } \\
\text { prolonged oxygen dependence until } \\
1 \text { year and } 7 \text { months of age. Emphysema } \\
\text { of right middle lobe, bronchomalacia of } \\
\text { right bronchial tree }\end{array}$ & $\begin{array}{l}\text { Tachypnea with desaturations, } \\
\text { pulmonary arterial hypertension, } \\
\text { oxygen dependence until } 22 \\
\text { months of age bilateral pulmonary } \\
\text { atelectasis and cysts. } \\
\text { Tracheobronchomalacia }\end{array}$ & $\begin{array}{l}\text { Recurrent cyanotic events, respiratory } \\
\text { distress, episodes of choking and vomiting, } \\
\text { with associated bronchospasm pulmonary } \\
\text { arterial hypertension, prolonged oxygen } \\
\text { and ventilator dependence until death at } \\
15 \text { months of age, bilateral pulmonary } \\
\text { emphysema and basal atelectasis tracheal } \\
\text { stenosis }\end{array}$ \\
\hline Chest X-ray & $\begin{array}{l}\text { Bilateral subsegmental atelectasis with } \\
\text { hyperlucent areas in both mid zones }\end{array}$ & & $\begin{array}{l}\text { Cystic pulmonary lesions alternating } \\
\text { with heterogeneous areas of } \\
\text { atelectasis }\end{array}$ & $\begin{array}{l}\text { Multiple subsegmental atelectasis and } \\
\text { areas of air trapping }\end{array}$ \\
\hline Chest CTscan & $\begin{array}{l}\text { Widespread peribronchial thickening, } \\
\text { subsegmental collapse, fluid within } \\
\text { oblique fissure, eventration of the left } \\
\text { hemidiaphragm }\end{array}$ & $\begin{array}{l}\text { Severe lobar emphysema of right middle I } \\
\text { obe with displacement of medistinal } \\
\text { structures to left and compression of left } \\
\text { upper lobe }\end{array}$ & $\begin{array}{l}\text { Patchy ground-glass appearance } \\
\text { with area of hyperinflation and } \\
\text { cystic pulmonary lesions alternating } \\
\text { with heterogeneous areas of } \\
\text { atelectasis and thickening of } \\
\text { interlobar septa }\end{array}$ & $\begin{array}{l}\text { Bilateral lower lobe airspace diseases, } \\
\text { hyperinflation of both upper lobes, } \\
\text { enlarged main pulmonary artery, right } \\
\text { aberrant subclavian artery, compressing } \\
\text { esophagus and trachea }\end{array}$ \\
\hline Surgery & $\begin{array}{l}\text { Subtotal upper lobectomy at age of } \\
8 \text { months for lobar emphysema. }\end{array}$ & $\begin{array}{l}\text { Lobectomy of right middle lobe for lobar } \\
\text { emphysema }\end{array}$ & & \\
\hline Lung histology results & $\begin{array}{l}\text { Panpulmonary emphysema with global } \\
\text { absence of bronchial cartilage and } \\
\text { hypertensive pulmonary vascular disease }\end{array}$ & Lung emphysema without inflammation & $\begin{array}{l}\text { Mild to moderate chronic lung } \\
\text { disease with associated alveolar } \\
\text { simplification and pulmonary } \\
\text { hypertension }\end{array}$ & $\begin{array}{l}\text { Alveolated lung parenchyma with alveolar } \\
\text { simplification }\end{array}$ \\
\hline $\begin{array}{l}\text { The associated } \\
\text { nonpulmonary features }\end{array}$ & $\begin{array}{l}\text { Periventricular nodular heterotopia with } \\
\text { left cerebellar hemisphere hypoplasia and } \\
\text { cisterna magna, truncal hypotonia, PDA, } \\
\text { aortic root dilatation, bifid right urinary } \\
\text { drainage system supraumbilical hernia, } \\
\text { macrothrombocytes }\end{array}$ & $\begin{array}{l}\text { Periventricular nodular heterotopia, with } \\
\text { an enlarged retrocerebellar cyst, secundum } \\
\text { atrial septal defect and coarctation of the } \\
\text { aorta, hypotonia, severe hyperlaxity }\end{array}$ & $\begin{array}{l}\text { Periventricular nodular heterotopia, } \\
\text { secundum atrial septal defect, mild } \\
\text { axial hypotonia }\end{array}$ & $\begin{array}{l}\text { Suspected periventricular nodular heterotopia, } \\
\text { PDA, angiogenesis causing dysphagia lusoria, } \\
\text { hypotonia and joint laxity }\end{array}$ \\
\hline Outcomes & Follow-up to 6 years & Follow-up to 3 years & Follow-up to 22 months & Death at 15 months \\
\hline
\end{tabular}


vascular endothelial cells that show defective cell-cell contacts and adherens junctions. The result is abnormal angiogenesis with disorganized blood vessels and aberrant branching [7, 12]. There are other possible pulmonary phenotypes of FLNA gene mutation suggested due to its role in $\mathrm{T}$ cell activation, interleukin production [13], inflammatory signaling [14], and interaction with the cystic fibrosis transmembrane conductance regulator [15]. There has been no specific sensitivity to infections observed in FLNA patients [10]. However, our patient was noted to have severe prolonged courses of viral or bacterial infections. The pathogenic variant of FLNA gene mutation in our reported case is not confirmed to have association with periventricular nodular heterotopias $(\mathrm{PNH})$, and our patient was too ill to complete brain MRI. The patient's mother has epilepsy beginning in the third decade of life. The patient's father has Behcet's disease, which is highly consistent with other reports of $\mathrm{PNH}[8,16,17]$.

\section{Conclusions}

In conclusion, we support the three previous reports in the literature, stating that there is an association between FLNA gene mutation and lung disease. The lung disease is a lethal condition likely manifested by early onset of pneumonia and recurrent bronchiolitis, subsequent asthma, pulmonary hypertension, and long-term oxygen dependency with underlying lung emphysema or lung cysts. FLNA mutation is also associated with airway anomalies such as tracheal stenosis (as in our patient) or tracheobronchomalacia. In addition, there are other diverse associated clinical manifestations.

\section{Consent}

Written informed consent was obtained from the patient's legal guardian for publication of this case report and any accompanying images. A copy of the written consent is available for review by the Editor-in-Chief of this journal.

\section{Abbreviations \\ FLNA: filamin A; GERD: gastroesophageal reflux disease; MRI: magnetic resonance imaging; PDA: patent ductus arteriosus; PNH: periventricular nodular heterotopia.}

\section{Competing interests}

The authors declare that they have no competing interests.

\section{Authors' contributions}

All authors were involved in the writing and editing of the manuscript. All authors read and approved the final manuscript.

Received: 27 July 2015 Accepted: 15 March 2016

Published online: 18 April 2016

\section{References}

1. Masurel-Paulet A, Haan E, Thompson EM, Goizet C, Thauvin-Robinet C, Tai A, et al. Lung disease associated with periventricular nodular heterotopia and an FLNA mutation. Eur J Med Genet. 2011;54:25-8.
2. Feng $Y$, Walsh CA. The many faces of filamin: a versatile molecular scaffold for cell motility and signalling. Nat Cell Biol. 2004;6:1034-8.

3. Fox JW, Lamperti ED, Ekşioğlu YZ, Hong SE, Feng Y, Graham DA, et al. Mutations in filamin 1 prevent migration of cerebral cortical neurons in human periventricular heterotopia. Neuron. 1998;21:1315-25.

4. Roberson S, Twigg S, Sutherland-Smith A, Biancalana V, Gorlin R, Horn D, et al. Localized mutations in the gene encoding the cytoskeletal protein filamin A cause diverse malformations in humans. Nat Genet. 2003;33:487-91.

5. Sheen VL, Dixon PH, Fox JW, Hong SE, Kinton L, Sisodiya SM, et al. Mutations in the X-linked filamin 1 gene cause periventricular nodular heterotopia in males as well as in females. Hum Mol Genet. 2001;10:1775-83.

6. Sheen V, Jansen A, Chen M, Parrini E, Morgan T, Ravenscroft R, et al. Filamin A mutations cause periventricular heterotopia with Ehlers-Danlos syndrome. Neurology. 2005;64:254-62.

7. de Wit M, Kros J, Halley D, de Coo I, Verdijk R, Jacobs B, et al. Filamin A mutation, a common cause for periventricular heterotopia, aneurysms and cardiac defects. J Neurol Neurosurg Psychiatry. 2009;80:426-8.

8. Lu J, Sheen V. Periventricular heterotopia. Epilepsy Behav. 2005;7:143-9.

9. Nurden P, Debili N, Coupry I, Bryckaert M, Youlyouz-Marfak I, Solé G, et al. Thrombocytopenia resulting from mutations in filamin A can be expressed as an isolated syndrome. Blood. 2011;118:5928-37.

10. de Wit M, Tiddens $\mathrm{H}$, de Coo I, Mancini G. Lung disease in FLNA mutation: confirmatory report. Eur J Med Genet. 2011;54:299-300.

11. Lord A, Shapiro AJ, Saint-Martin C, Claveau M, Melançon S, Wintermark P. Filamin A Mutation may be associated with diffuse lung disease mimicking bronchopulmonary dysplasia in premature newborns. Respir Care. 2014;59(11):e171-7.

12. Yu N, Erb L, Shivaji R, Weisman GA, Seye Cl. Binding of the P2Y2 nucleotide receptor to filamin A regulates migration of vascular smooth muscle cells. Circ Res. 2008;102:581-8.

13. Hayashi K, Altman A. Filamin A is required for T cell activation mediated by protein kinase C- $\theta$. J Immunol. 2006;177:1721-8.

14. Leonardi A, Ellinger-Ziegelbauer H, Franzoso G, Brown K, Siebenlist U. Physical and functional interaction of filamin (actin-binding protein-280) and tumor necrosis factor receptor-associated factor 2. J Biol Chem 2000;275:271-8

15. Thelin WR, Chen Y, Gentzsch M, Kreda SM, Sallee JL, Scarlett CO, et al. Direct interaction with filamins modulates the stability and plasma membrane expression of CFTR. J Clin Invest. 2007;117:364-74.

16. Battaglia G, Chiapparini L, Franceschetti S, Freri E, Tassi L, Bassanini S, et al. Periventricular nodular heterotopia: classification, epileptic history, and genesis of epileptic discharges. Epilepsia. 2006;47:86-97.

17. d'Orsi G, Tinuper P, Bisulli F, Zaniboni A, Bernardi B, Rubboli G, et al. Clinical features and long term outcome of epilepsy in periventricular nodular heterotopia. Simple compared with plus forms. J Neurol Neurosurg Psychiatry. 2004;75:873-8.

Submit your next manuscript to BioMed Central and we will help you at every step:

- We accept pre-submission inquiries

- Our selector tool helps you to find the most relevant journal

- We provide round the clock customer support

- Convenient online submission

- Thorough peer review

- Inclusion in PubMed and all major indexing services

- Maximum visibility for your research 